\title{
Effect of Optimum Sized Solar PV Inverter on Energy Injected to AC Grid and Energy Loss in Pakistan
}

\author{
Munwar Ayaz Memon* and Ghullam Mustafa Bhutto \\ Department of Electrical Engineering, Quaid-e-Awam University of Engineering \\ Science and Technology, 67480, Pakistan
}

\begin{abstract}
Article Type: Article
Article Citation: Munwar Ayaz Memon, Ghullam Mustafa Bhutto. Effect of optimum sized solar PV inverter on energy injected to AC grid and energy loss in Pakistan. Indian Journal of Science and Technology. 2020; 13(08), 954-965. DOl: 10.17485/ ijst/2020/v013i08/149950
\end{abstract}

Received date: January 27, 2020

Accepted date: February 15, 2020

*Author for correspondence: Munwar Ayaz Memon $\nabla$ engr. mam@quest.edu.pk $९$ Department of Electrical Engineering, Quaid-e-Awam University of Engineering Science and Technology, 67480, Pakistan

\begin{abstract}
Objective: To analyze the effect of optimized size inverter for Nawabshah Sindh Pakistan on the annual energy injected to ac grid and energy loss. Methods: Using the optimized sizing ratio of 1.4664, which is the ratio of rated photovoltaic system to the rated inverter size the simulations are carried out in MATLAB for $3 \mathrm{~kW}$ and $50 \mathrm{~kW}$ photovoltaic systems. A comparison between the conventional sized system that is the photovoltaic system and inverter of the same size and optimized system where the photovoltaic inverter is connected with respect to the sizing ratio are taken and simulations are carried out using real time data of solar irradiation and ambient temperature of Nawabshah Sindh Pakistan in MATLAB for one year. Findings: It is seen that $5830 \mathrm{kWh}$ and $97,162 \mathrm{kWh}$ energy is annually injected to the utility grid or load and annual power loss of $274 \mathrm{kWh}$ and $4568 \mathrm{kWh}$ from conventional sized $3 \mathrm{~kW}$ and $50 \mathrm{~kW}$ PV systems, respectively. While the annual energy injected to the ac grid is $5852 \mathrm{kWh}$ and $97,529 \mathrm{kWh}$ and annual power loss of $252 \mathrm{kWh}$ and $4201 \mathrm{kWh}$ from optimized sized $3 \mathrm{~kW}$ and $50 \mathrm{~kW}$ PV systems, respectively. Novelty: Thus, we can say that the optimized system not only reduces the size of the inverter but also improves the system efficiency and reduces the losses which eventually decreases the capital cost of the PV system and energy production.
\end{abstract}

Keywords: Distributed Generation, PV System, Energy Loss, PV Integration, Inverter sizing Ratio.

\section{Introduction}

In the socioeconomic development of any country, a vital role of electrical energy is seen. A continuous increase in the electrical energy utilization is seen due to an increase in the population, advanced technology usage, etc. [1-2]. Since last two decades, a load shading 
of 10-12 h/day is faced by the peoples of Pakistan due to a shortfall of electrical energy even though at about $43 \%$ population is living without electricity and about 50,000 small villages are far away from the excess to national grid [3-4]. A major share of electricity in Pakistan is produced from conventional sources such as oil, gas, coal, etc., which are imported thus an increase in the fuel price directly affects the cost of the electricity [5-6]. An increase in the energy demand and dependency on conventional sources is a great concern the world is facing nowadays. These sources result in environmental pollution and contributing to global warming by releasing carbon dioxide to the atmosphere [7-8]. In order to decrease the dependency on conventional energy sources and difference between supply and demand of energy, it is the need of the present era to alter the conventional energy sources to renewable energy sources such as wind, solar, biomass, etc. with low cost and zero carbon emission [9-10]. Nowadays, the capacity of PV power generation has increased from $\mathrm{kW}$ to MW in various countries around the world, a $303 \mathrm{GW}$ solar power production is expected by 2020 in the global power production [11-12]. Photovoltaic generating units require low maintenance cost; noise-free and without a rotating part compared to the fossil fuel energy generating units [13]. A massive initial cost of photovoltaic system is one of the key concerns although it is a clean, environmental friendly and secure energy source [14-16]. The power produced by PV panel is intermittent, uncertain, and random in nature as it depends on the meteorological data of the site, such as irradiation and ambient temperature because PV panels are designed under standard test conditions of $1000 \mathrm{~W} / \mathrm{m}^{2}$ irradiations and $25^{\circ} \mathrm{C}$ ambient temperature [17]. The Solar Photovoltaic System is the best solution for the distributed power generation as the sunlight is freely available. Without affecting the environment dc power is produced by SPV system when photo energy strikes on it. SPV system can be operated in standalone and grid-tied mode. Generally standalone SPV systems are used in rural areas which are far away from the national grid and gridconnected systems are used in urban areas in order to supply the excess energy produced by SPV systems to the national grid and receive the energy in case of shortage or any fault [18-19]. In order to connect the photovoltaic system to the distribution grid a voltage source inverter is used, which converts the dc power generated from PV system to ac power injected to the utility grid [8-20]. TypicallyPV system and inverter of same size are used, but it is seen that the irradiations and ambient temperature of the sites are below the standard test conditions hence the power generated by photovoltaic system is always under the designed capacity. Therefore the size of the inverter must be optimized in order to supply the power reliably and efficiently [14, 21-22]. A major portion of capital cost is utilized on the inverter purchase therefore the optimized size inverter also reduces the cost of the photovoltaic system.

The single line diagram of the proposed research work with the integration of solar panels is developed in Dig SILENT power factory software using real time data is shown in Figure 1.

To optimize the inverter size, the load of one of the class of electrical engineering department QUEST Nawabshah is calculated and is shown in Table 1. In order to supply a $2.5 \mathrm{~kW}$ load, an inverter of $3 \mathrm{kVA}$ is chosen, whose specifications [23] are shown in Table 2 and the characteristics of PV panels [24] utilized at the site are shown in Table 3. 


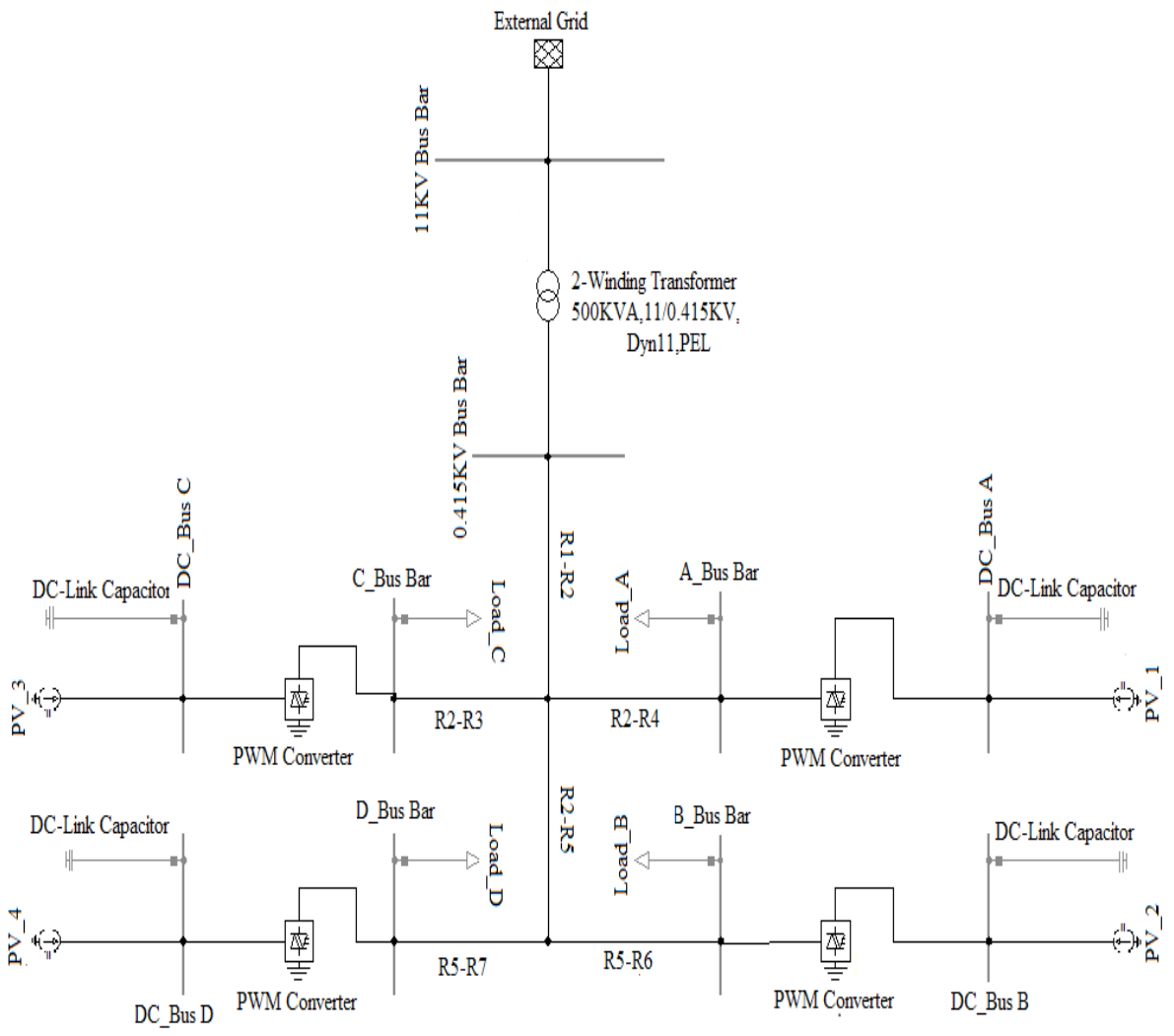

FIGURE 1. Model of distribution system with the integration of solar panels.

TABLE 1. Load of final year class of electrical engineering department

\begin{tabular}{clcc}
\hline S. no. & \multicolumn{1}{c}{ Load name with power rating } & Quantity & Total power \\
\hline 1 & Electric tube lights $(40 \mathrm{~W})$ & 16 & 640 \\
2 & Electric fans $(80 \mathrm{~W})$ & 12 & 960 \\
3 & Multimedia and speakers $(900 \mathrm{~W})$ & 01 & 900 \\
Total load of class & & & 2500 Watt \\
\hline
\end{tabular}

TABLE 2. 3 kVA inverter stipulations

\begin{tabular}{ll}
\hline Type & Hybrid \\
Power rating & $3 \mathrm{~kW}$ \\
Input direct current & \\
Minimum input direct current voltage & $360 \mathrm{~V}$ \\
Peak input direct current voltage & $500 \mathrm{~V}$ \\
Start-up voltage & $116 \mathrm{~V} \mathrm{DC} / 150 \mathrm{~V}$ \\
Maximum power point voltage & $250 \mathrm{~V}$ DC to $450 \mathrm{~V}$ \\
Peak input current & $13 \mathrm{~A}$
\end{tabular}




\section{Inverter AC output}

Minimum voltage

$208,220,230,240 \mathrm{~V}$

Frequency range

47.5 to $50.2 \mathrm{~Hz}$

Minimum current

$13.6 \mathrm{~A}$

Power factor

Greater than 0.99

TABLE 3. Characteristics of solar module

Nominal output power (Pmpp)

Cell type

Open circuit voltage (V)

Short circuit current (A)

Maximum power point voltage $(\mathrm{V})$

Maximum power point current (A)

Module efficiency (\%)

Temperature co-efficient of maximum power $\left(\% /{ }^{\circ} \mathrm{C}\right)$

Temperature co-efficient of open circuit Voltage $\left(\% /{ }^{\circ} \mathrm{C}\right)$

Temperature co-efficient of short circuit current $\left(\% /{ }^{\circ} \mathrm{C}\right)$

Nominal operating cell temperature $\left({ }^{\circ} \mathrm{C}\right)$

Operating temperature $\left({ }^{\circ} \mathrm{C}\right)$

\section{$250 \mathrm{~W}$}

Poly-crystalline silicon cell

37.4

8.7

30.9

8.1

15.3

$-0.41$

$-0.31$

0.039

$46 \pm 2$

-40 to 85

Figures 2 and 3 shows the annual hourly average solar irradiance and ambient temperature data [25] of site (QUEST Nawabshah) where the photovoltaic system is installed.The aim of this paper is to compare the effect of optimum sized inverter on the annual energy injected to ac grid and its effect on annual energy loss with respect to the conventional sized inverter.

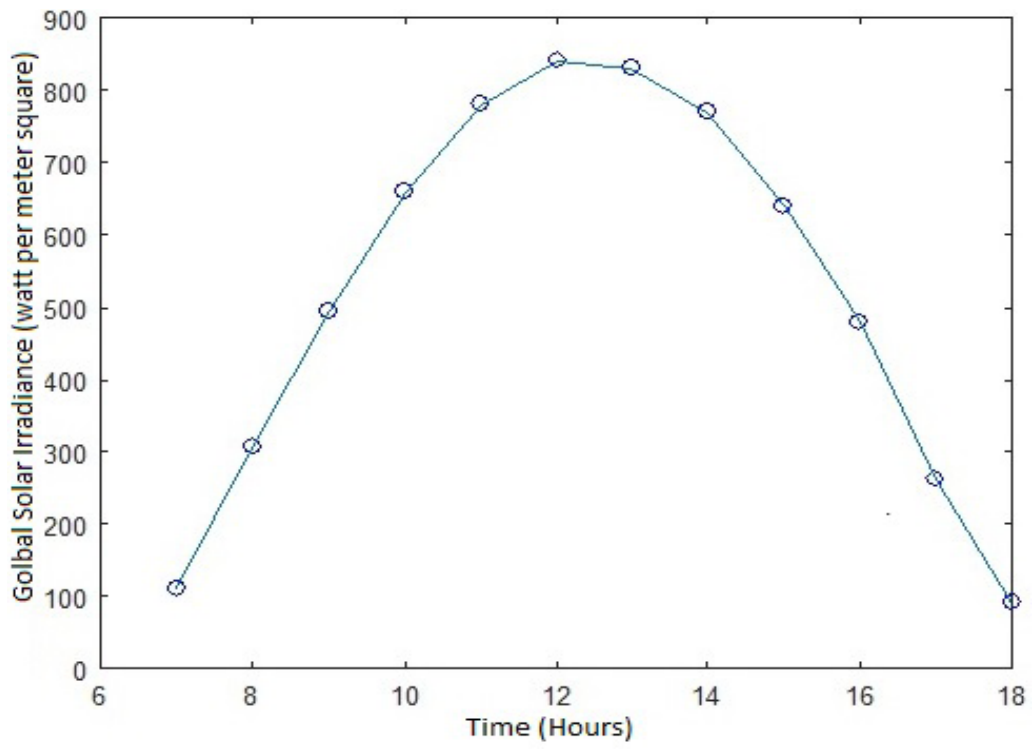

FIGURE 2. Global solar radiations data at quest. 


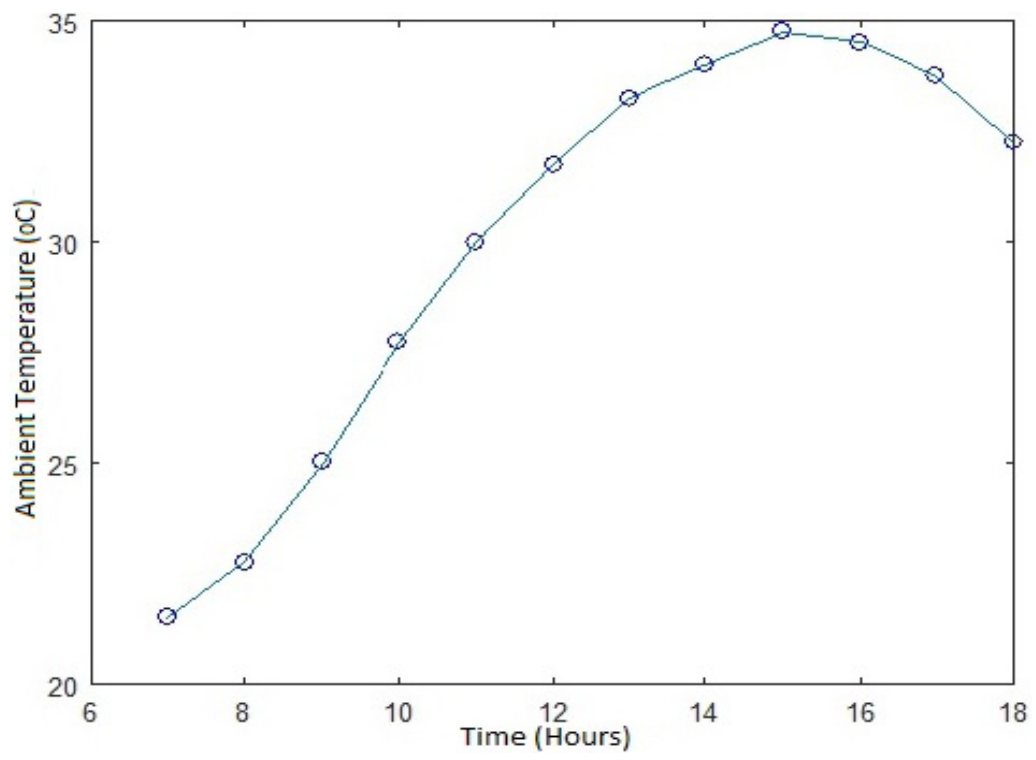

FIGURE 3. Ambient temperature data at quest.

\section{PV Array Output Power}

The electrical power of photovoltaic panels depends on the irradiance and cell temperature [26]. A linear relationship with irradiance and non-linear relationship with cell temperature of PV panel power output is seen beyond the standard test conditions. The PV panel output power can be calculated by using Equation (1),

$$
P_{p v(\text { out })(t)}=\operatorname{Ppeak}\left(\frac{G(t)}{G s \tan d a r d}\right)[1-\alpha(T c-25]
$$

where $P_{p v(\text { out }(t)}, G(t)$, and Tc are the instantaneous output power of solar panel, irradiance, and cell temperature, respectively, Ppeak is maximum expected output power of solar panel at standard test conditions i.e. $1000 \mathrm{~W} / \mathrm{m}^{2}$ irradiance and $25^{\circ} \mathrm{C}$ cell temperature and $\alpha$ is the temperature coefficient of power which is $-0.41 \% /{ }^{\circ} \mathrm{C}$ taken from polycrystalline $\mathrm{PV}$ panel datasheet.

Therefore, in order to determine the output power, the instantaneous cell temperature of photovoltaic modules can be calculated using Equation (2),

$$
\mathrm{Tc}=\mathrm{Ta}+\left[\frac{(\mathrm{NOCT}-20)}{800}\right] * \mathrm{G}(\mathrm{t})
$$

where Ta and NOCT are the instantaneous ambient temperature and normal operating cell temperature taken from solar panel data sheet.

Using MATLAB Simulink the instantaneous cell temperature and output power of 3 $\mathrm{kW}$ photovoltaic system is simulated and is shown in Figures 4 and 5, respectively. 


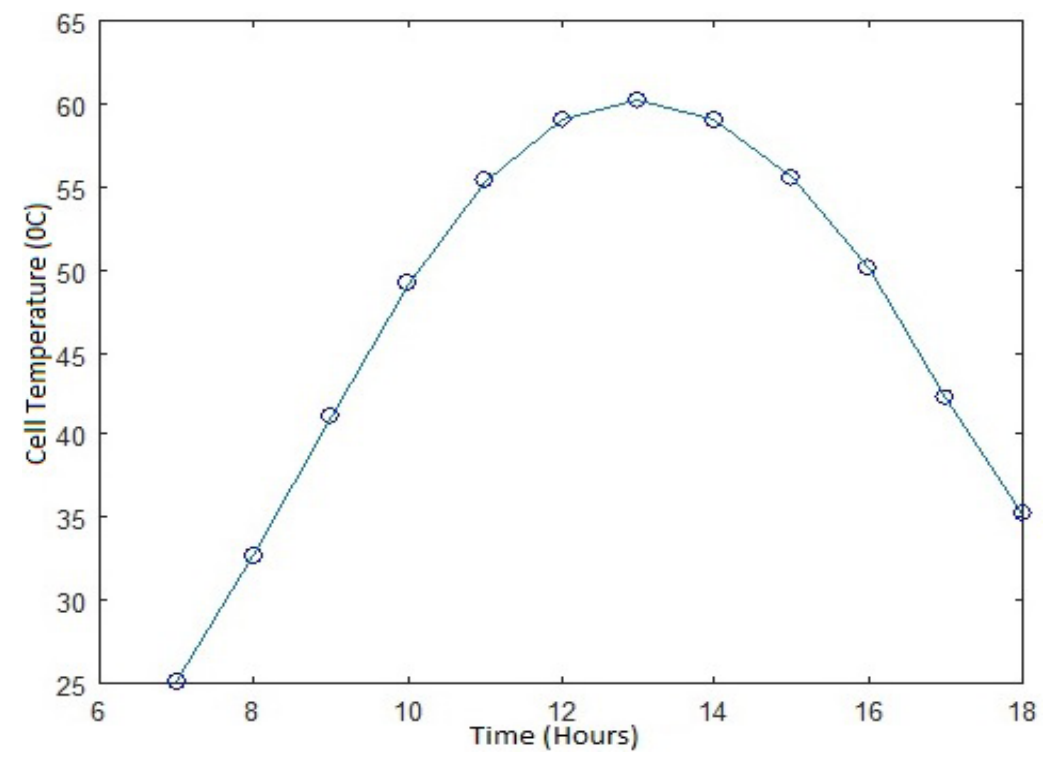

FIGURE 4. Cell temperature of PV panel installed at the site.

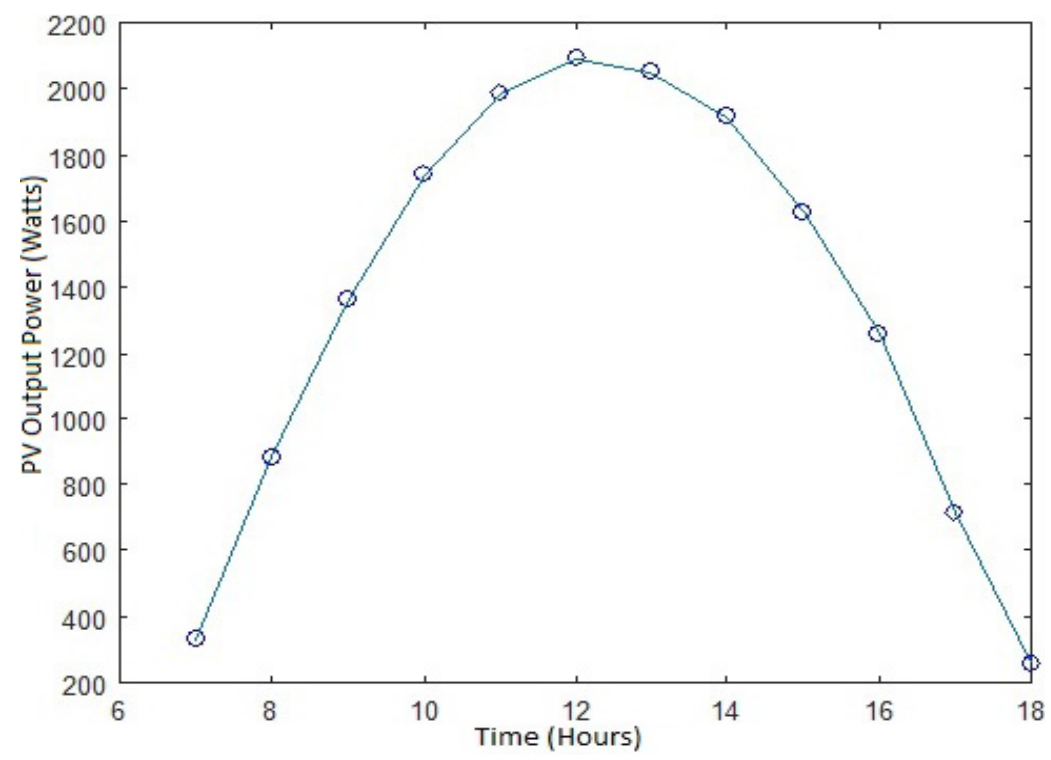

FIGURE. 5. Output power of solar system installed at the site.

\section{Inverter Efficiency Curve and Its Optimization}

The efficiency of photovoltaic inverter [26] may be defined as the ratio of ac output power injected to ac grid to the dc power produced by PV panels input to the inverter as in Equation (3), 


$$
\eta_{\text {inv }}=\frac{\mathrm{P}_{-} \mathrm{ac}(\mathrm{t})}{\mathrm{P}_{-} \mathrm{dc}(\mathrm{t})}=\left(\frac{\mathrm{P}_{\mathrm{dc}(\mathrm{t})}-\mathrm{P}_{\mathrm{loss}(\mathrm{t})}}{\mathrm{P}_{\mathrm{dc}(\mathrm{t})}}\right)
$$

where $\mathrm{P}_{-} \mathrm{dc}(\mathrm{t}), \mathrm{P}_{-\mathrm{ac}(\mathrm{t})}$, and $\mathrm{P}_{-} \operatorname{loss}(\mathrm{t})$ are the instantaneous direct current output power of PV system, the alternating current power supplied to the load/utility grid, and conversion power loss respectively.

Using MATLAB Simulink the inverter efficiency curve is developed as shown in Figure 6, using the inverter model presented in Equation (4) developed by [15, 26] in terms of inverter input power to output power.

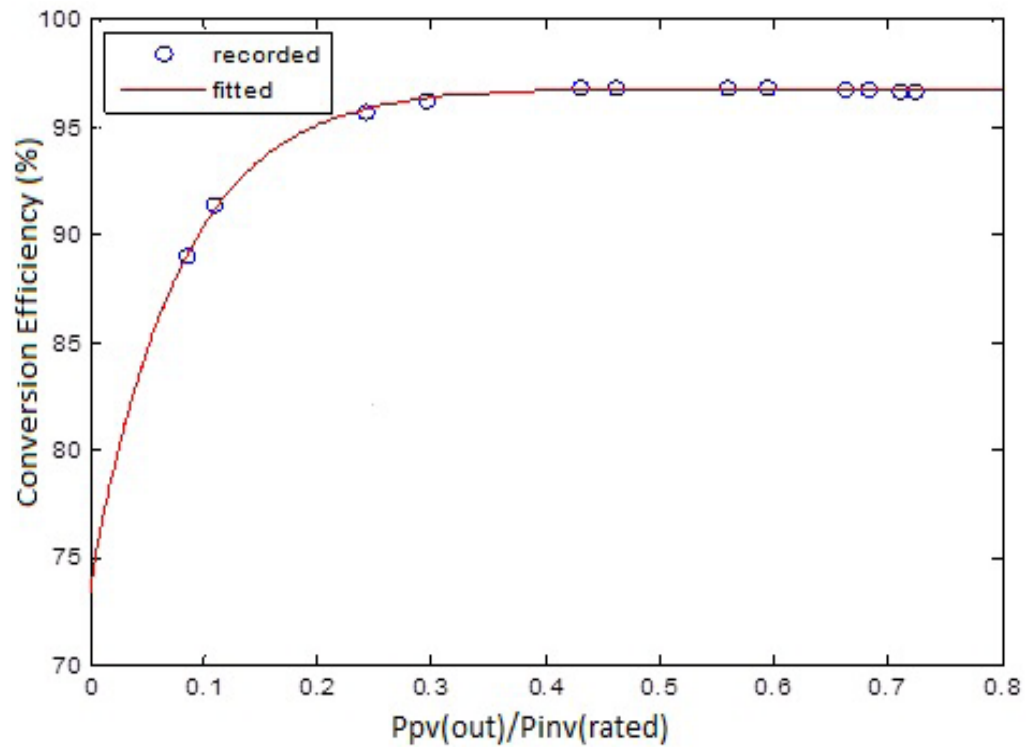

FIGURE 6. Efficiency curve of the inverter installed at site.

$$
\eta_{i n v}=100.583-(\text { Pratio x3.611 })-\left(\frac{0.972}{\text { Pratio }}\right)
$$

Where,

$$
\text { Pratio }=\frac{\mathrm{P}_{\mathrm{pv}(\text { out })(\mathrm{t})}}{\text { Pinv }(\text { rated })}
$$

The efficiency curve shown in Figure 6 is described by an exponential function as follows.

$$
\begin{gathered}
\eta_{i n v}=a_{e}^{b x}+c_{e}^{d x} \text { when } x>0 \\
\eta_{i n v}=0 \text { when } x=0
\end{gathered}
$$


where $x=\frac{\mathrm{P}_{\mathrm{pv}(\text { out })(\mathrm{t})}}{\operatorname{Pinv}(\text { rated })}$ and $\mathrm{a}, \mathrm{b}, \mathrm{c}$, and $\mathrm{d}$ are the model coefficients.

Using MATLAB fitting tool, the developed inverter model coefficients are determined and are described as in Table 4.

TABLE 4. Inverter model co-efficient

\begin{tabular}{ccccc}
\hline Inverter rating & A & B & C & D \\
\hline $3 \mathrm{~kW}$ & 96.97 & -0.003816 & -23.55 & -12.79 \\
\hline
\end{tabular}

The sizing ratio $[15,26]$ may be defined as the ratio between photovoltaic systems rated power to the inverter rated power and can be expressed as in Equation (6);

$$
\text { Rs }=\frac{\text { Ppeak }}{\text { Pinv }(\text { rated })}
$$

When $0<R s<1$, it means that the oversized inverter is used and when Rs $>1$ it means that the undersized inverter is used. As the aim of the inverter size optimization is to obtain the average possible maximum annual efficiency from inverter which is given as in Equation (7),

$$
\varsigma_{\text {Max:annual Avrg }}=\sum_{i=1}^{366} \frac{\mathcal{c}_{\text {daily avrg }}}{366}
$$

Figure 7 shows the flow chart of the program and outcomes. An iterative loop is used with a set of Rs values from 0.5 to 5 with a gap of 0.01 . The loop is repeated iteratively

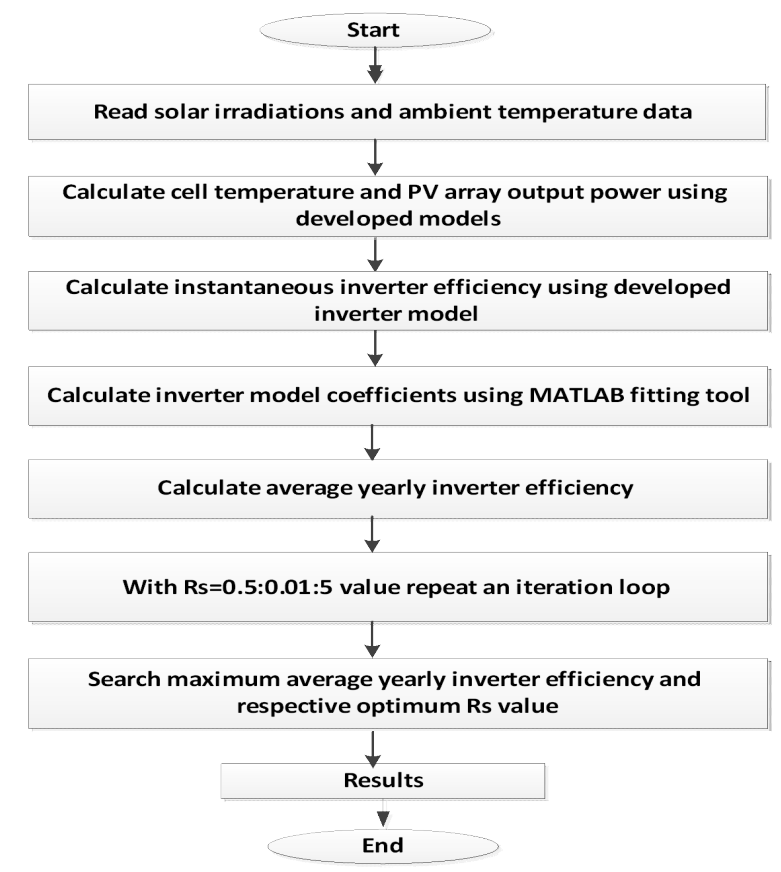

FIGURE 7. Flow chart of the program and outcomes. 


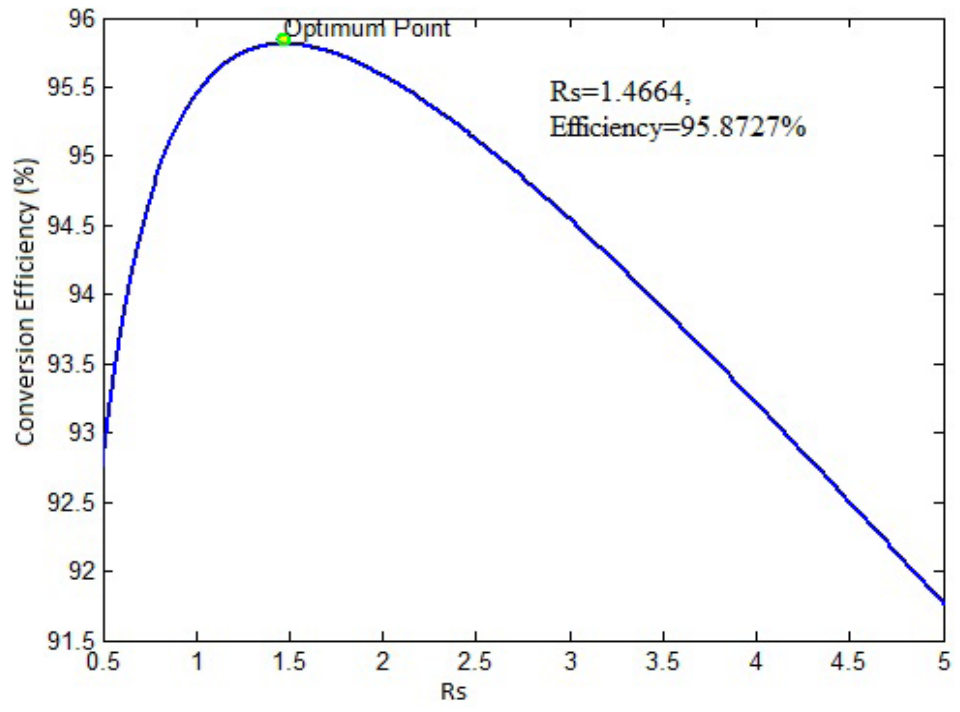

FIGURE 8. Optimal inverter size and maximum average annual efficiency for Nawabshah Sindh Pakistan.

until the sizing ratio reaches its peak value than a search is done in order to determine the maximum annual average efficiency and the optimum sizing ratio which is $95.8727 \%$ with a sizing ratio of 1.4664 . Figure 8 shows the optimal inverter size and maximum average annual efficiency for Nawabshah Sindh Pakistan.

\section{Comparison Between the Conventional and Proposed System}

In order to validate the proposed optimization a $3 \mathrm{~kW}$ and $50 \mathrm{~kW}$ PV systems are taken and comparison between conventional sized inverter and optimized one is simulated in MATLAB and the results are tabulated in Table 5.

TABLE 5. Comparison between conventional and optimized PV system

\begin{tabular}{lllll}
\hline & \multicolumn{2}{c}{ Conventional sized system } & \multicolumn{2}{c}{ Optimized system } \\
\hline PV system rated power (kW) & 3 & 50 & 3 & 50 \\
Inverter rated power (kVA) & 3 & 50 & 2.046 & 34.10 \\
Sizing ratio Rs & 1 & 1 & 1.4664 & 1.466 \\
\%age of inverter size w.r.to PV system & 100 & 100 & 68.2 & 68.2 \\
$\begin{array}{l}\text { Average annual output energy from } \\
\text { PV system (kWh) }\end{array}$ & 6104 & 101730 & 6104 & 101730 \\
$\begin{array}{l}\text { Annual average conversion efficiency } \\
\text { Average annual energy injected to }\end{array}$ & $95.51 \%$ & $95.51 \%$ & $95.87 \%$ & $95.87 \%$ \\
grid (kWh) & 5830 & 97162 & 5852 & 97529 \\
Annual power loss (kWh) & 274 & 4568 & 252 & 4201 \\
\hline
\end{tabular}




\section{Conclusion}

It is concluded that the optimized system's performance is better than conventional sized system. As the average annual energy injected to the ac grid is $5830 \mathrm{kWh}$ and 97,162 $\mathrm{kWh}$ and annual power loss of $274 \mathrm{kWh}$ and $4568 \mathrm{kWh}$ from conventional sized $3 \mathrm{~kW}$ and $50 \mathrm{~kW}$ PV systems, respectively. While the average annual energy injected to the ac grid is $5852 \mathrm{kWh}$ and $97,529 \mathrm{kWh}$ and annual power loss of $252 \mathrm{kWh}$ and $4201 \mathrm{kWh}$ from optimized sized $3 \mathrm{~kW}$ and $50 \mathrm{~kW}$ PV systems, respectively. Thus we can say that the optimized system not only decreases the inverter size but also enhances the efficiency of the system and reduces the losses which eventually decreases the capital cost of the PV system and energy production.

\section{Acknowledgement}

We are thankful to Quaid-e-Awam University of Engineering Science and Technology Nawabshah Sindh Pakistan for facilitating in conducting the research work.

\section{References}

1. Dharavath R, Raglend IJ, Atul Manmohan. Implementation of solar pv-battery storage with DVR for power quality improvement. In: IEEE International conference on innovations in power and advanced computing technologies, India. 2017; 1-5. doi:10.1109/IPACT.2017.8245134

2. Irfan M, Zhao ZY, Ahmed M, Mukeshimana MC. Solar energy development in Pakistan: barriers and policy recommendations. Sustainability. 2019, 11(4), 1206-1214. DOI: 10.3390/ su11041206.

3. RehmanJatoi A, Raza Samo S, Jakhrani AQ. Influence of temperature on electrical characteristics of different photovoltaic module technologies. International Journal of Renewable Energy Development. 2018, 7(2), 85-91. DOI: 10.14710/ijred.7.2.85-91.

4. Jamil I, Zhao J, Zhang L, Rafique SF, Jamil R. Uncertainty analysis of energy production for a $3 \times 50 \mathrm{MW}$ AC photovoltaic project based on solar resources. International Journal of Photoenergy. 2019, 1-12. DOI: 10.1155/2019/1056735.

5. Khalil MS, Khan NA, Mirza IA. Renewable energy in Pakistan: status and trends. Pakistan Alternative Energy Development. 2014. https://pdfs.semanticscholar.org/9e1c/64a4badb2836b 5882ca985f121a5acf92c73.pdf

6. Harijan K, Uquaili MA, Mujeebuddin Memon. Renewable energy for managing energy crisis in Pakistan. Communications in Computer and Information Science. 2008, 20, 449-455. DOI: 10.1007/978-3-540-89853-5_48.

7. Mohamed A, Eltamaly AM, Farh HM, Alolah AI. Energy management and renewable energy integration in smart grid system. In: IEEE, international conference on smart energy grid engineering (SEGE '15), Canada. 2015; 1-6. DOI: 10.1109/SEGE.2015.7324621.

8. Mohsen S. Over-view of grid-connected two-stage transformer-less inverter design. Journal of Modern Power System and Clean Energy. 2018, 6(4), 642-655. DOI:10.1007/s40565.

9. Valasai GD, Uqaili MA, Memon HUR, Saleem Raza Samo, Mirjat NH, Khanji Harijan. Overcoming electricity crisis in Pakistan: a review of sustainable electricity options. Renewable and Sustainable Energy Review. 2017, 72, 734-745. DOI: 10.1016/j.rser.2017.01.097. 
10. Mirza IA, Sana Ahmed, Shahid Khalil M. Renewable energy in Pakistan: opportunities and challenges. A Scientific Journal of COMSAT-Science Vision. 2011, 16 \& 17, 13-20. http://www. sciencevision.org.pk/BackIssues/Vol16_Vol17/02_Vol16_and_17_Renewable\%20Energy\%20 in\%20Pakistan_IrfanAfzalMirza.pdf

11. Peng XY, SO PL, Tan KT. An analysis on system frequency of a smart grid network with largescale PV power generation. IEEE PES Asia-Pacific power and energy engineering conference (APPEEC), Hong Kong, China, 2014; 1-6. DOI: 10.1109/APPEEC.2014.7066128.

12. Alsafasfeh Q, Saraereh O, Khan I, Kim S. Solar PV grid power flow analysis. Sustainability. 2019, 11(6), 1744. DOI: 10.3390/su11061744.

13. Saidi AS, Marwa Ben Slimene, ArbiKhlifi M. Transient stability of photovoltaic system with experimental shading effects. Engineering Technology and Applied Science Research. 2018, 8(6), 3592-3597. https://www.etasr.com/index.php/ETASR/article/view/2384

14. Tamer Khatib, Azah Mohamed, K. Sopian. A review of photovoltaic systems size optimization techniques. Renewable and Sustainable Energy Reviews.2013, 22, 454-465. DOI: 10.1016/j. rser.2013.02.023.

15. Tamer Khatib. Optimization of a grid connected renewable energy system for a case study in Nablus Palestine. International Journal of Low Carbon Technologies. 2014, 9(4), 311-318. DOI: 10.1093/ijlct/ctt007.

16. Tamer Khatib, Azah Mohamed, K. B. Sopian, M. Mahmoud. A new approach for optimal sizing of standalone photovoltaic systems.International Journal of Photo energy. 2012, 2012, 1-7. DOI: $10.115 / 2012 / 391213$.

17. Hussain SM, Rahim MH, Zunaira Nadeem, Iqra Fatima, ZafarIqbal, Asif S, Javaid N. The trends of integrating renewable energy sources: a survey. Lecture Notes on Data Engineering and Communication Technologies. 2017, 12, 627-637. DOI: 10.1007/978-3-319-69811-3_56.

18. Sivaprasad A, Kumaravel S, Ashok S. Integration of solar pv/battery hybrid system using dual input dc-dc converter. In: IEEE biennial international conference on power and energy systems, towards sustainable energy, India, 2016; 1-5. DOI: 10.1109/PESTSE.2016.7516473.

19. Latreche S, Essalam A, Khemliche M. Implementation of MPPT algorithm and supervision of shading on photovoltaic module. Engineering Technology and Applied Science Research. 2018, 8(6), 3541-3544. https://www.etasr.com/index.php/ETASR/article/view/2354

20. Reddy NA, Raju KD. Mathematical modeling of soft switched single stage multistring inverter with multi-rated ETT photovoltaic modules. International Journal of Advanced Research, Ideas and Innovations in Technology. 2017, 3(1), 489-499. https://www.ijariit.com/manuscripts/v3i1/ V3I1-1301.pdf

21. Zhu J, Brundlinger R, Betts TR, Gottschalg R. Effect of module degradation on inverter sizing. In: $33^{\text {rd }}$ IEEE photovoltaic specialist conference Sandiego, USA. 2008; 1-6. DOI: 10.1109/ PVSC.2008.4922867.

22. Demoulias C. A new simple analytical method for calculating the optimum inverter size in gridconnected pv plants. Electric Power System Research. 2010, 80(10), 1197-1204. DOI: 10.1016/j. epsr.2010.04.005.

23. 3KVA inverter specifications. https://www.google.com/search?rlz=1C1GCEA_enPK768 PK768\&ei=SSUsXrfYFYGx8gKdq7OoDg\&q=3kw+solar+inverter+specifications\&oq=3kva +solar+inverter+spe\&gs_l=psy-ab.3.1.0i22i3012j0i333.7484.17674..19423...0.2..3.376.4975.213j5..............gws-wiz.....0..0i71j0i13j0i13i30j0i13i5i30j0i273j0j0i67.Z2QRBt2ziBA: Dated assessed: 2019.

24. Hyundai solar module RG series. https://www.wholesalesolar.com/cms/specs-3330439735.pdf. www.hhigreen.com. Date accessed: 2019. 
25. Jatoi AR, Samo SR, Jakhrani AQ. An improved empirical model for estimation of temperature effect on performance of photovoltaic modules. International Journal of Photoenergy. 2019, 1-16. DOI: 10.1155/2019/1681353.

26. Khatib T, Yasin A, Ali A. Mohammad, Ibrahim Anwar Ibrahim. On the effectiveness of optimally sizing an inverter in a grid-connected photovoltaic power system. In: IEEE14th international conference on smart cities: improving quality of life using ICT \& IoT (HONET-ICT), Jordan. 2017; 4-52. DOI: 10.1109/HONET.2017.8102220. 